\title{
Election proximity and representation focus in party-constrained environments
}

\author{
Jorge M Fernandes \\ University of Bamberg, Germany \\ Cristina Leston-Bandeira \\ University of Leeds, UK \\ Carsten Schwemmer \\ University of Bamberg, Germany
}

\begin{abstract}
Do elected representatives have a time-constant representation focus or do they adapt their focus depending on election proximity? In this article, we examine these overlooked theoretical and empirical puzzles by looking at how reelectionseeking actors adapt their legislative behavior according to the electoral cycle. In parliamentary democracies, representatives need to serve two competing principals: their party and their district. Our analysis hinges on how representatives make a strategic use of parliamentary written questions in a highly party-constrained institutional context to heighten their reselection and reelection prospects. Using an original data set of over 32,000 parliamentary questions tabled by Portuguese representatives from 2005 to 2015, we examine how time interacts with two key explanatory elements: electoral vulnerability and party size. Results show that representation focus is not static over time and, in addition, that electoral vulnerability and party size shape strategic use of parliamentary questions.
\end{abstract}

\section{Keywords}

electoral cycle, electoral vulnerability, parliamentary questions, parliamentary party groups, political representation

\section{Introduction}

Do elected representatives have a time-constant representation focus or do they adapt their focus depending on election proximity? In this article, we address these overlooked theoretical and empirical puzzles by examining how representatives use parliamentary questions to serve their competing principals - their districts and their party-over time. The effect of election proximity has been extensively examined in the US literature, particularly for roll-call voting (Amacher and Boyes, 1978) and bill sponsoring (Fenno, 1982; Kessler and Krehbiel, 1996). Using an original data set with over 32,000 parliamentary questions in Portugal for a period of three legislatures (2005-2015), our main argument is that representatives in parliamentary democracies make a strategic use of their prerogative of tabling questions over the course of the electoral cycle. ${ }^{1}$

Our original contribution hinges on the interaction of time with electoral vulnerability and party size. By analyzing how representatives with different electoral vulnerabilities and from parties of different sizes ask questions to the government, we disentangle the incentives to shirk and to free ride on the parliamentary party group's collective effort to build a reputation (Cox and McCubbins, 2005). The latter is instrumental for reelection purposes, particularly in Portugal, where there is no individual representation of candidates in the ballot. Under those circumstances, representatives have to channel their individual prerogatives, such as parliamentary questions, toward building an attractive party label. This need is particularly

Paper submitted 25 July 2016; accepted for publication 29 December 2016

\section{Corresponding author:}

Jorge M. Fernandes, University of Bamberg, Feldkirchenstraße, 2I, Bamberg 96045, Germany.

Email: jorge.fernandes@uni-bamberg.de 
heightened for electorally vulnerable representatives. As for party size, the bigger the party structure, the higher the incentives to shirk and free ride, if for nothing else, because of the increasingly high costs for the leadership to monitor their members' behavior.

Results suggest that time plays an important role in explaining the focus of representation. Representatives adapt their behavior strategically, depending not only on their personal electoral circumstances (electoral vulnerability), the structure in which they are embedded (party size), but also on the moment of the electoral cycle (election proximity).

\section{Representatives and parties in parliamentary democracies}

Political parties are the most important organizational unit of political life in parliamentary democracies, through which the citizenry (the principals) select representatives (the agents) to act on their behalf and hold them accountable (Müller, 2000). In legislatures, parties help reduce transaction costs, facilitate the coordination of information acquisition and dissemination, and promote the division of labor (Aldrich, 1995). They play "an important role in selecting presiding officers, in allocating legislators to committees, and to leadership positions within committees, and in shaping the agenda for consideration of bills and other measures" (Rasch, 1999: 123).

Typically, the division of labor inside parliamentary party groups is intimately connected with committee organization. Two examples illustrate this. In Belgium, De Winter and Dumont say that parties "organize a tour d'horizon during their weekly parliamentary party group meeting, during which committee members orally present the main topics that will be discussed and decided by their respective committee" (2000: 114). In Sweden, "the internal division of labor corresponds to the Riksdag committee system. This means that committee assignments have an impact on who is responsible for specific subject areas within the party group" (Hagevi, 2000: 149). The party's leadership is responsible for the allocation of members to committees, taking into consideration preferences, seniority, and position in the party hierarchy (Fernandes, 2016). In return, parties expect members to specialize in policy areas and to deliver information to party's median legislator to curb uncertainty in policy outcomes (Gilligan and Krehbiel, 1987), acquiring and disseminating information at the intra-party level with minimum agency loss (Kiewet and McCubbins, 1991).

Representatives have three paramount goals: to be reelected, to have influence on the chamber, and to extract good public policy (Fenno, 1973). More recently, Kam reminds us that "politicians desire a combination of policy influence, office perks, and votes" and that reelection is a means to an end, which may be a "desire to serve their communities or to make a difference, but it may also involve securing a particular policy outcome" (2009: 21-22). Representatives devise strategies to help them "most successfully and efficiently act to maximize the likelihood of whatever outcomes they favour" (Strøm, 1997: 158). Those strategies are influenced by the institutional setting in which representatives operate.

In parliamentary democracies, political parties hold the monopoly of candidate selection (Sartori, 1976). Consequently, to be successful in reelection, representatives need, first, to succeed in being reselected by the party selectorate (Strøm, 1997). In addition, representatives need to have "access to the party label and its privileges in campaigning and the electoral process" (Sieberer, 2006: 154). The pivotal role of political parties for the reelection process, which is instrumental for the attainment of policy influence and sway in the chamber, makes them the leading principal for representatives. As Carey states "virtually all legislators are subject to influence by at least one principal: their legislative party leadership. Whether they are subject to pressure from other, competing principals depends on the institutional context in which they operate" (2007: 93).

Electoral rules help explain the centrality of political parties for representatives' strategies. They determine the incentives to cultivate a personal vote, defined as "that part of the legislator's vote that is based on his or her individual characteristics or record" (Shugart et al., 2005: 437). In some electoral contexts, for example, Single-Transferable Vote (STV) systems, representatives have not only to compete at the inter-party level, but also at the intra-party level (Katz, 1986). In the latter, representatives have to cater their constituency to earn voters' support at the expense of their fellow party members (Carey and Shugart, 1995). Thus, being reselected by the party is a necessary, but not a sufficient condition for reelection, which has implications for parliamentary strategies. For example, the Irish STV electoral system heightens the likelihood for representatives to table parliamentary questions related to their constituency to signal to voters that they are looking after their interests (Martin, 2011).

Conversely, in closed-list proportional systems, where the party holds the monopoly for selecting and ranking candidates, being reselected might be a sufficient condition. In this case, the party leadership becomes the leading principal to which representatives have to work for. Because in these contexts electoral competition is reduced to an inter-party dimension, there is a decrease in the incentives for representatives to deliver constituency-focused benefits (Carey and Shugart, 1995).

The competition between party and district for representatives' focus is further mitigated by district magnitude and electoral vulnerability. The former affects the likelihood that representatives will shirk and free ride on their fellow candidates' efforts. The higher the district magnitude, the less costly for a candidate to focus on her own goals while 
other party candidates are working to deliver public goods, particularly in nonpreferential systems (Bowler and Farrell, 1993). Moreover, electoral vulnerability will also play a role in the extent to which representatives are willing to serve their party or their constituents (Cain et al., 1987). According to André et al.,

legislators in safe seats will be the first to shirk and free ride. Legislators in marginal seats, by contrast, will be most motivated to overcome any shirking or free riding, even if the gains from their constituency effort are limited by the electoral institutions. (2015: 468)

\section{Parliamentary questions as indicators of representatives' foci}

For a long time overlooked, parliamentary questions have recently received more attention from the legislative scholars' community. Labeled foremost as a scrutiny tool, they are in fact a cornerstone of nonlegislative activities in legislatures and their uses are manifold. Representatives use them for a wide range of purposes: to request information from the executive, to gain publicity, to surf a wave of antigovernmental popular sentiment, to foster their reputation on a particular policy field, as well as for strategic electoral signals to the selectorate and the electorate (Bailer, 2011; Proksch and Slapin, 2011; Russo and Wiberg, 2010; Wiberg, 1995). In addition, parliamentary questions are an inexpensive tool for what Saalfeld (2000a) dubs of fire-alarm oversight. Although not always focusing on the big stories, parliamentary questions constitute an effective vehicle for opposition parties to collate detailed information and thereby build a wealth of material on a wide range of issues (Sánchez de Dios and Wiberg, 2011). Furthermore, recent work has emphasized their importance to influence the public agenda (Green-Pedersen, 2010). Parliamentary questions can also be used effectively by representatives to signal dissent from the official party line in a variety of institutional contexts (Leston-Bandeira, 2009). Briefly, as Rozenberg and Martin state, "what is striking is the diversity of uses of parliamentary questions explaining why they have great "heuristic potential" (2011: 394), as they can be a very good insight into legislators' behavior.

The variety of ways in which parliamentary questions are used reflects their versatility as a legislative tool. As Sánchez and Wiberg demonstrate, there are almost as many types and combinations of parliamentary questions as legislative institutional arrangements (2011: 218-221). Although the UK Prime Minister's Question (PMQ) time is the most well-known type of parliamentary questions, they are but typical of this scrutiny tool. PMQs are the prime of what oral questions in the plenary can offer in terms of visibility, theatre, and political scoring. However, in reality, the vast majority of parliamentary questions are written questions, unknown to most people. As GreenPedersen states, "(w)ritten questions, the vast majority in most countries, rarely receive much direct attention" (2010: 350). While oral questions may have some visibility, written questions tend to have barely any and to focus on specific policy issues, according to government departments, often verging on the highly technical.

Typically, extant literature on parliamentary questions hinges on the assumption that these are inherently individual-level legislative tools (Wiberg, 1995). For example, Rozenberg and Martin claim that "parliamentary questions are amongst the most sincere measures of what interests legislators, free from party control" (2011: 398). In highly constrained institutional environments, such as the Portuguese one as we shall see below, these constitute, therefore, unique tools whereby parties offer legislators leeway not only to select topics but also to choose when to use them.

Literature on the internal organization of parliamentary party groups, however, disputes the assumption that parliamentary questions are inherently individual tools, unconstrained from party control. In Germany, for example, "questions, which have not been tabled as a result of an explicit decision of the parliamentary party group's caucus are expected to be cleared with the relevant party working groups, executive committees, and whips' offices" (Saalfeld, 2000b: 27). Similarly, in the Netherlands, "parliamentary parties also require their members to seek permission before making use of individual parliamentary rights, such as putting a written question to a minister" (Andeweg, 2000: 99, italic in the original).

In this article, we build on the assumption that parliamentary questions are an individual instrument that representatives use in coordination with the party leadership aiming at maximizing collective benefits to the party (Cox and McCubbins, 1993). Such assumption hinges on the idea that "the parliamentary and extra-parliamentary party leadership will expect the member's loyalty and diligent service in a variety of arenas" (Strøm, 1997: 162). Party reputation is of particular importance in nonpreferential electoral systems in which voters cast a ballot for a party label. According to Cox and McCubbins, "the more favorable is the [...] party's record of legislative accomplishment, the better its reputation or brand name will be" (Cox and McCubbins, 2005: 7). Representatives' individual parliamentary questions will help to cement the party's reputation, to acquire and disseminate information to the median legislator, and to balance information asymmetry between the government and the opposition, particularly as elections approach and opposition parties strive for information for the electoral campaign. Ultimately, "the better [...] the party's brand name, the better will be the prospects for (re)election" (Cox and McCubbins, 2005: 7). 


\section{Competing principals in the Portuguese parliament}

The Portuguese parliament, the Assembleia da República, is a party-based legislature. Representatives are first and foremost expected to be the delegates of their party, whereby the link between elected officials and voters is done via the party (Converse and Pierce, 1986; Pequito Teixeira, 2009). The legislature is composed of 230 representatives, who are elected through a closed-list proportional system, according to the d'Hondt highest average method. Portuguese representatives are therefore elected through lists determined by their parties. When a voter goes to the ballot box, they see a list of party symbols - no specific name of deputies is indicated. People explicitly vote for the party. The country is divided into 22 separate districts. Division by districts, however, merely exists for administrative reasons.

Similar to France (Costa et al., 2012), the Portuguese representative mandate is a national one. Constituencies as such have no meaning in the Portuguese political ethos. Not only does the word and associated meaning do not exist in Portuguese but also the Constitution specifically states that deputies represent the whole country rather than their specific districts (Article 152). Accordingly, deputies elected through, for instance, Lisbon or Porto, should have the same mandate. Besides this, the constitution also specifically forbids regionally based parties (Article 51) and simultaneously confers to the party the monopoly on representation in the legislature. In addition, resources and parliamentary rights are allocated to parliamentary groups (the party's facet in the legislature), rather than legislators. Consequently, parliamentary activity provides a privileged channel to communicate to voters as well as to explain party policy preferences.

The highly constrained party environment notwithstanding, there is a twofold incentive for representatives to focus on their district. First, legislators often also have local representative mandates-again a similarity with French cumul de mandats (Blais, 2006), whereby national representatives accumulate this role with positions in the local government structure. Second, thanks to a well-embedded system of substitutions that involves temporary mandate suspensions, well-known local representatives, including Mayors, are able take on their mandate in the legislature, where they have incentives to table questions for their districts.

Crucially, Portuguese representatives can put forward as many written questions to the government as they wish. This is one of the few parliamentary rights ascribed to legislators individually and not constrained by a party quota, whereas oral questions to the government are ascribed to parliamentary groups according to their size - giving groups a full control of who asks what - written questions are submitted by representatives individually.
While parliamentary groups have overall supervision of the type of areas that require detailed questioning, deputies are also able to submit their own questions.

Parliamentarians use different types of questions to suit different circumstances and purposes. In particular, written questions assist representatives in asking far more precise and well backed-up questions than oral questions would enable them to. Written questions are therefore dually important. They give a new vehicle for parties to present their policy preferences to voters and they introduce a more flexible tool, whereby deputies have flexibility of action regardless of their parties. As Rozenberg et al. have shown, questions to the government can give a valuable insight into representatives' behavior, unveiling policy, and foci preferences (2011). This is particularly important in the context of the top-down, partyfocused, type of structure that permeates the organization of Portuguese parliamentary groups.

Representatives part of the group's directorate - president of the group, vice presidents, and policy coordinators-constitute what would often be referred to as frontbenchers. ${ }^{2}$ These constitute the well-known faces of each parliamentary group, those the public would recognize from press conferences, speaking on television, in short the faces personifying their parties. In small parliamentary groups, such as the Left Bloc (BE), the Portuguese Communist Party (PCP-PEV), or the Christian Democratic Party (CDS-PP), they represent most of the group. However, in the larger parties, such as the Socialist Party (PS) or the right-liberal Social Democrat Party (PSD), they can only constitute at the most a third of the parliamentary group. The other two-thirds are representatives with considerably reduced visibility and level of responsibility. Taking into account that "constituency work" as such does not really punctuate the activity of a Portuguese representative, it soon becomes clear that there is a job gap to be filled in, which is neither the frontline action, nor pursuing local constituents' issues. This is where written questions can become a useful tool for parliamentary activity, but also to help us understand the subtleties of the pressures exercised by competing principals such as party and local districts.

\section{Hypotheses}

The theoretical framework outlined above leads to several empirically testable hypotheses. First, we start by looking at the effect of electoral vulnerability on legislators' incentives to focus primarily on the district or on their party in their parliamentary questioning activities. Following André et al. (2015), our expectation is that those representatives who have been elected in safe seats will table fewer parliamentary questions with a district focus. Such expectation is based on the idea that representatives who have a higher certainty in their reelection will have more incentives to 
free ride and to contribute less for the party's collective good (Olson, 1965), that is, the grassroots work at the district level. Those legislators will feel privileged to serve the party as their main principal and to ensure that their privileged position in the electoral list remains untouched. Conversely, legislators who have previously been placed by the party leadership in a relatively unsafe position will focus on serving the district to heighten the party's aggregate electoral prospects and, in turn, help their own reelection. This is particularly important for closed-list proportional representation systems, like Portugal, where party labels are the sole electoral heuristics for voters.

H1: The lower their electoral vulnerability, the more likely that representatives will table party-focused parliamentary questions.

Second, we look at the effect of the size of the parliamentary party group on the incentives for legislators to focus on serving their district or their party in parliamentary questions. Panebianco (1988) observed that size impacts party organizational structures and bureaucratization, reflected in labor division within parliamentary party groups (Heidar and Koole, 2000). The size of the organization is important to understand the transaction costs associated with decision-making (Nooteboom, 1993). Inherently, small parties do not have enough scale for specialization because there are simply not enough members to deal with the institutional workload. In those parties, the hierarchical dividing line between frontbenchers and backbenchers is much more blurred than in larger parliamentary party groups. Our expectation is for the size of parliamentary party groups to have a positive effect on the likelihood of representatives to focus on district service. Two reasons explain this. First, larger groups promote shirking and free riding, decreasing the incentives of its members to help the formation of collective goods through information acquisition and dissemination to the median legislator. Rather, under these circumstances, representatives will have more incentives to focus on their district. Second, an increase in the group's size will increase the costs for the parliamentary leadership to keep tabs on individual behavior, which, in turn, further facilitates free riding.

H2: The larger the size of the parliamentary party group, the more incentives for representatives to table a district-focused parliamentary question.

Third, we introduce a time-dynamic approach to parliamentary questions. Extant literature shows that election proximity changes legislators' behavior by making them more focused on the principal holding the key to their reelection (Elling, 1982; Lindstadt and Wielen, 2011; Thomas, 1985). For example, Fenno shows that, in the United States, "the roll-call or other policy-related behavior of senator changes in the direction of policy sentiments of their electorate as their reelection approaches" (1982: 36). We build on this literature to understand the effect of election proximity in written questions. Our overall expectation is that representatives will adapt their behavior over time by making a strategic use of parliamentary questions. This should work as a moderating effect of electoral vulnerability and party size.

First, we expect election proximity to encourage legislators with high vulnerability to make more district-focused questions. To be sure, those legislators will have more incentives to work for the party label as a collective good and to signal at the district level that they are concerned with the electorate (Cox and McCubbins, 2005). In a different vein, legislators with low electoral vulnerability will face no risk of not getting reelected. Thus, they will have lower incentives to work for their district. In fact, low electoral vulnerability positions are reserved to frontbenchers, who, as Election Day approaches, will be responsible, for example, to use the legislative arena to build the party's national profile and retrieve information from the government and the bureaucracy for electoral purposes.

Second, electoral proximity has a different impact depending on the size of the parliamentary party group. In all parties, as Election Day approaches, the parliamentary leadership needs to prepare for the elections, getting involved in coordination activities, supporting party leadership drafting the manifesto, and so forth. As Farrell and Webb underline, "changes in campaign personnel reflect a general shift in the internal power relations within parties, with the parliamentary face - and especially that part of it intimately associated with the party leadership - emerging as the main power house" (2000: 121). Thus, there is an increase in opportunity costs as Election Day approaches, in that the parliamentary leadership must decide whether to devote its human resources and time to monitor backbenchers or to invest in campaign activities (Shepsle et al., 2009). We assume that the leadership chooses to focus on campaign activities. Consequently, its institutional capacity to keep tabs on backbenchers will be weakened as Election Day approaches, paving the way for the latter to shirk and free ride more easily. Inherently, in small parties, the labor division between frontbenchers and backbenchers will be blurred because they are short on personnel. By and large, in big parties, there is a clear-cut division between the parliamentary leadership and the backbenchers. As Election Day approaches, the former will be increasingly more involved in campaign activities and less in everyday business in parliament. The latter will not only free themselves from leadership control but also will have a job gap to be filled in, with the decreasing importance of parliamentary activities as elections approach.

H3a: The fewer the days to the next general election, the more likely that representatives with low electoral vulnerability will table a question focusing on their party. 
H3b: The fewer the days to the next general election, the higher the incentives for representatives of big parties to shirk and free ride by tabling a question focusing on their district.

\section{Data and methods}

These hypotheses are tested using all parliamentary written questions over three legislative periods in Portugal: 2005-2009, 2009-2011, and 2011-2015. Our original data set includes a total of 32,011 parliamentary questions. Data has been retrieved from official records available online in the Portuguese legislature's website. Our time period allows us to account not only for the potential effects of the 2007 parliament reform but also for the changes in the ideological nature of the executive and the majority size. There were multiple power constellations of government over these three legislative periods. In 2005, the Socialists held an absolute majority, followed by a plurality majority in 2009. Subsequently, in 2011, the rightist Social Democrats and Christian Democrats coalesced to form a postelectoral minimum winning coalition.

Our unit of analysis is the parliamentary question. The dependent variable Parliamentary Question Focus is specified as a nominal unordered variable with three categories such as trustee (0), district (1), and political party (2). Each parliamentary question is attributed to a value depending on whether the deputy tabled a question focused on her interests as a trustee (0), a question focusing on the district in which she has been elected (1), or a question focusing on delivering benefits to the political party (2).

The empirical measure of focus of representation of each parliamentary question has been conducted as follows. To be coded as district focused (1), a parliamentary question has to make an explicit and direct reference to a geographic unit in the deputy's district. By geographic unit, we mean either a reference to the district as a whole (e.g., Lisbon) or a direct reference to a city or parish in the district (e.g., Sintra or São Domingos de Rana). We have used an automated process to match the parliamentary questions with information from the National Statistics Office (Instituto Nacional de Estatística), as an official source for districts, municipalities, and parishes. ${ }^{3}$

Our dependent variable takes the value of 2 if the deputy tables a question to the ministry shadowed by the committee in which she sits. ${ }^{4}$ We build on previous findings on the strong connection between labor division within the parliamentary party group and committee assignment (Hagevi, 2000). Parties assign members to committees and, in return, the latter will be considered as experts and have particular duties in that respective policy. In the Portuguese legislature, representatives have to specify the departmental ministry to which they want to submit their written question. Thus, if a representative tables a question to the "Health
Ministry" and, at the same time, sits on the Health Committee, there is a matching constellation.

A question takes the value of 0 when deemed as a trustee issue. For analytical purposes, we have chosen this as the baseline category of our dependent variable. Trustees work as a neutral category against which the other two categories - district and party-are compared. In the Portuguese system, there is not only a low level of legislative professionalization but also a high turnover. Consequently, many legislators keep private activities while in office and must nurture those interests to help them in their postparliamentary career. The trustee category encapsulates all questions neither related to party nor district. For example, a legislator with strong private environmental interests might table several questions on this topic, albeit not working directly to serve her party on those matters, or the constituency. While this tells us little about the representative's specific interests, it does signal those instances when representatives act according to their own individual interests and judgments, rather than that of competing principals between district and party audiences. For further information, including examples, please see the online appendix.

We include three independent variables of interest. First, we measure Electoral Vulnerability, whose main purpose is to account for the representative's relative position in the electoral list and the safety of that position. ${ }^{5} \mathrm{We}$ expect this variable to shape representatives' behavioral incentives to focus on party or district. Those representatives with lower electoral vulnerability will have more incentives to focus on the party because their chances of being reselected and reelected are higher (Sieberer, 2006). To be sure, in a closed-list proportional representation system, representatives with high electoral vulnerability will have incentives to work for their district by heightening the party's record as a vehicle for constituents' interests. ${ }^{6}$ This variable is measured using a formula presented in André et al. (2015), dividing the seat order of the candidate by the party's seat total in the district. The original scale ranges from 0 to $1 .^{7}$ For example, a candidate elected as top of the list (number 1) in a district where the party elected four representatives has an electoral vulnerability of 0.25 , while a candidate elected in fourth yields 1 .

Second, we include Party Size, a measure in percentage of the number of seats that the parliamentary party group controls in the plenary. Our third independent variable of interest is Election Proximity, a continuous measuring capturing the elapsing time from the day the parliamentary question has been tabled until the official day of the next scheduled general election. ${ }^{8}$

Our models further include three control variables. First, we measure Seniority by counting the number of mandates that representatives have served in the legislature. Previous research has suggested that the more mandates representatives have served, the more encapsulated they will be from deselection and electoral defeat, with decreasing levels of 
Table I. Determinants of parliamentary question focus in the Portuguese legislature.

\begin{tabular}{|c|c|c|c|c|c|c|}
\hline & \multicolumn{2}{|c|}{ Model I } & \multicolumn{2}{|c|}{ Model 2} & \multicolumn{2}{|c|}{ Model 3} \\
\hline & District & Party & District & Party & District & Party \\
\hline $\begin{array}{l}\text { Electoral } \\
\text { vulnerability }\end{array}$ & $-0.02(0.25)$ & $-0.80 * * *(0.58)$ & $-0.12 *(0.04)$ & $-1.15^{* * *}(-0.10)$ & $-0.02(0.03)$ & $-0.80 * * *(-0.06)$ \\
\hline Party size & $0.04 * * *(0.01)$ & $0.12 * * *(0.01)$ & $0.02 * * *(0.01)$ & $0.05^{* * * *}(0.03)$ & $0.03 * * *(0.01)$ & $0.13^{* * *}(0.01)$ \\
\hline Election proximity & $0.01(2.00)$ & $0.01 * * *(0.01)$ & $0.01 * * *(2.98)$ & $0.01 * * *(0.01)$ & $0.01(0.01)$ & $0.01 * *(0.01)$ \\
\hline $\begin{array}{l}\text { Electoral } \\
\text { vulnerability } \times \\
\text { Election proximity }\end{array}$ & & & $-0.01 * * *(0.01)$ & $-0.0 \mathrm{I} * * *(-0.0 \mathrm{I})$ & & \\
\hline $\begin{array}{l}\text { Party size } \times \text { Election } \\
\text { proximity }\end{array}$ & & & & & $-4.55^{*}(2.33)$ & $6.72 * *(2.53)$ \\
\hline Seniority & $-0.10 * * *(0.01)$ & $-0.09 * * *(-0.01)$ & $-0.10 * * *(0.01)$ & $-0.08 * * *(0.01)$ & $-0.10^{* * *}(0.01)$ & $-0.09 * * *(-0.01)$ \\
\hline Government & $0.01(0.11)$ & $-1.4 I^{* * *}(0.14)$ & $0.0 I(0.1 I)$ & $-1.36 * * *(0.13)$ & $0.01(0.12)$ & $-1.40 * * *(-0.14)$ \\
\hline Local government & $0.38 * * *(0.03)$ & $0.42 * * *(0.03)$ & $0.39 * * *(0.33)$ & $0.45 * * *(0.35)$ & $0.38 * * *(0.32)$ & $0.42 * * *(0.03)$ \\
\hline Intercept & $-2.09 * * *(0.28)$ & $-4.24 * * *(0.30)$ & $-1.99 * * *(0.29)$ & $-0.45^{* * *}(0.35)$ & $-1.98 * * *(-0.29)$ & $-4.33 * * *(0.30)$ \\
\hline$N$ & &, 011 & & 011 & 32 & 011 \\
\hline $\mathrm{BIC}$ & -27 & 753.85 & -27 & '79.78 & -274 & 49.67 \\
\hline
\end{tabular}

Note: Coefficient entries estimated with multinomial logit regression. A control variable for party fixed effects is included in the model but not displayed. $*_{p}<0.05 ; * *_{p}<0.01 ; * * * p<0.001$ (two-tailed).

district service (Fenno, 1978). Second, we introduce a Government dummy that takes a value of 0 if the party is in the opposition and a value of 1 if the party is in government. Our expectation is that representatives in opposition parties will have environmental incentives to adapt their behavior and to focus more on serving their party. They have to do it because the party has fewer human and money resources compared to executive parties. Parliamentary questions are particularly important to curb information asymmetries and to signal to voters the policy agenda of the party (Rasch, 2011). Third, we include a Local Government dummy that takes a value of 1 for legislators with local roles and 0 otherwise.

\section{Results}

Our empirical foray into the foci of representation of representatives in the Portuguese legislatures fits a multinomial logit with three specifications (see Table 1). Model 1 includes all covariates, except for the interaction terms. We start by examining hypothesis 1 to understand the effect of electoral vulnerability on the likelihood for representatives to table questions focused on their party. Recall that our expectation is that low electoral vulnerability will increase the likelihood that representatives focus on their party by making a question to the ministry shadowed by the committee in which they sit. Empirical results support hypothesis 1 . The negative coefficient $(-0.80, p<0.001)$ points out that an increase in electoral vulnerability will make representatives less likely to focus on tabling question with a party focus compared with the reference category of trustee. True, the coefficient is equally negative for district (the other competing principal). However, not only it is smaller, but it also fails to reach conventional levels of statistical significance.

Turning to hypothesis 2 , according to which we expect party size to have an effect in the likelihood of representatives to table a district-focused question, empirical evidence suggests support for this hypothesis. An increase in party size heightens the likelihood for representatives to focus on their district, in that they have incentives to free ride on their colleague's work, but also because it becomes too costly for the party leadership to monitor their behavior. Consequently, in the Portuguese case, representatives from the Socialist and Social Democrat Party, whose size typically averages $40 \%$ of the plenary floor, have more incentives to focus on their district than their counterparts from small parties. Representatives from the Communist, the Left Bloc, and the Christian Democratic Party groups, averaging $10 \%$ of the floor, will be more likely to focus on their party. Interestingly, the covariate for party size for the Party specification in Model 1 yields a higher coefficient, and equally statistically significant, which is a puzzling result. We turn to this in our subsequent hypotheses.

In hypotheses $3 \mathrm{a}$ and $3 \mathrm{~b}$, we posited that the effect of electoral vulnerability and party size would both be moderated by election proximity. Representatives adapt their strategies to help their reelection, which becomes a more pressing goal toward the end of the legislative term. Let us enquiry first the interaction effect between electoral vulnerability and election proximity, as fitted in model 2. Figure 1 helps us to understand the results for the full range of values in the election proximity covariate (Brambor et al., 2006). The left-hand pane in Figure 1 shows the likelihood for tabling district-focused parliamentary questions across the legislative term for representatives in three different levels 


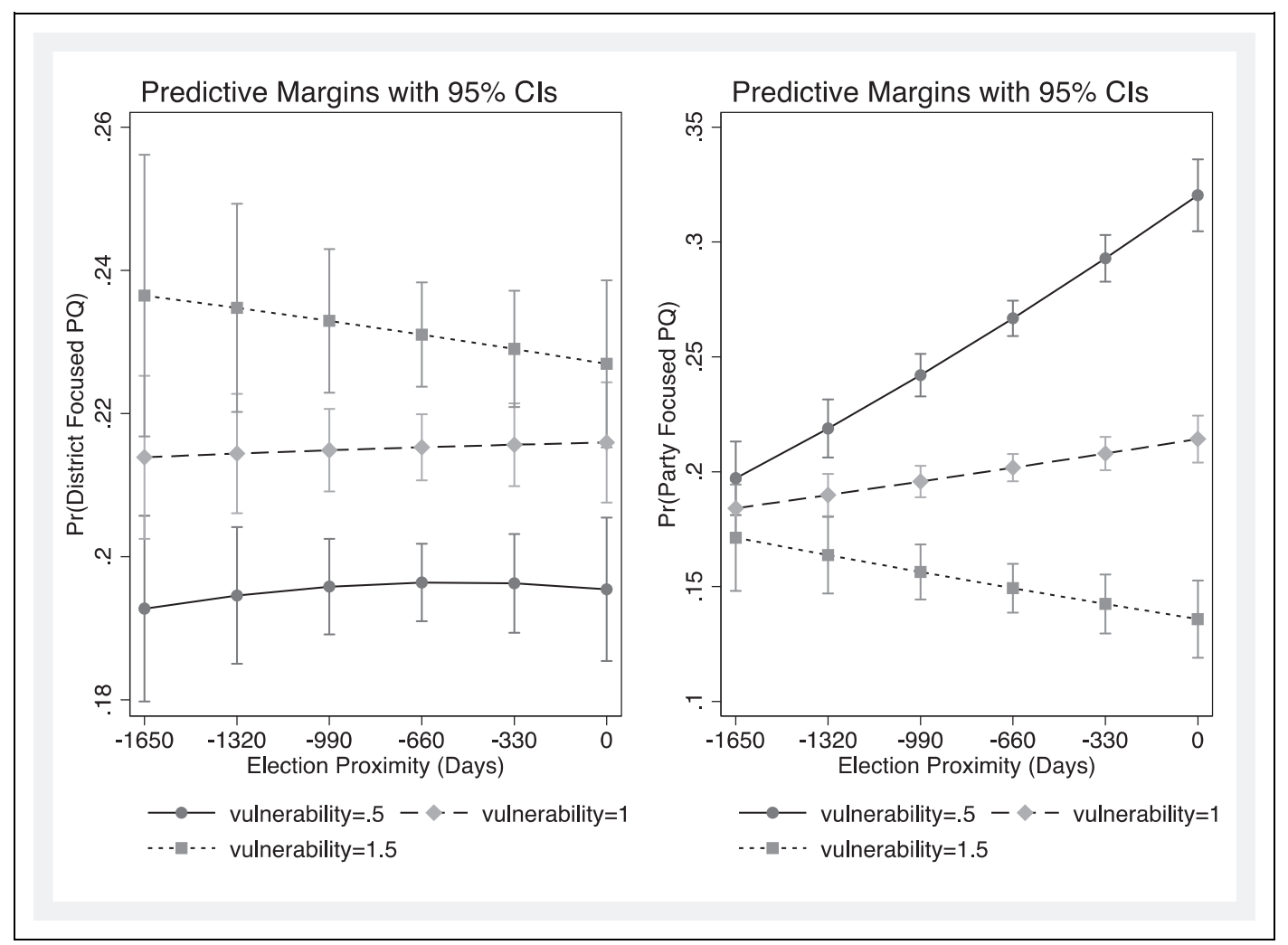

Figure I. Marginal effects of electoral vulnerability moderated by election proximity.

of electoral vulnerability. Overall, the results suggest that there are no major changes in the propensity to table a district-focused question for the three benchmarks of electoral vulnerability displayed here. In other words, representatives with $0.5,1$, and 1.5 electoral vulnerability levels have relatively constant levels of scoring this question, which means that time has a limited, if any, impact in this particular. Looking at the right-hand pane, we witness a different story. Evidence suggests that election proximity does have an impact in the likelihood that representatives table a party-focused question. The less electorally vulnerable representatives $(0.5$, solid line $)$ have a 10 -point increase from 0.21 to 0.31 in the likelihood of serving their party in their parliamentary questions. The more electorally vulnerable representatives (1.5, dotted line) have an opposite effect, that is, election proximity makes them to focus less on their party in their parliamentary questions. This evidence supports hypothesis $3 \mathrm{a}$.

Finally, we investigate the interaction effect between party size and election proximity, testing for hypothesis $3 \mathrm{~b}$. Figure 2 displays the marginal effects for the likelihood of representatives of parties of two sizes to table a parliamentary question focusing on their district (left pane) or on their party (right pane). ${ }^{9}$ On the left pane, evidence suggests that representatives in large parties $(40 \%$ of the plenary seats) have a decreasing activity in terms of the number of questions tabled focusing on their district. There is a 4-point decrease, from 0.12 to 0.08 , in the likelihood of focusing on their district from the beginning of the legislative term until the end. Small parties' representatives $(10 \%$ of the plenary seats) have a more stable behavior, with only a small change in their likelihood to focus on their district in their questions. Turning to the right-hand pane, we see that representatives in both small and large parties have a similar pattern. There is an increase in the likelihood of tabling a question focusing on the party as Election Day is near. The slope, however, is steeper for large parties, with a 0.09 -point increase from 0.69 to 0.78 . For small parties, the change accounts only to about 0.03 -point increase from 0.21 to 0.24 . Overall, evidence does not support hypothesis $3 \mathrm{~b}$. On the contrary, large parties' representatives focus less on their district as Election Day approaches.

Our models are robust to the inclusion of control covariates. Seniority has a negative effect for the likelihood of tabling parliamentary questions for both district and party, which seems to point out that, in line with Fenno's (1978) argument, representatives become more trustee-style the more senior they are. In line with Rasch's (2011) findings for Norway, our results also show that being in government decreases the likelihood of representatives to table a partyfocused parliamentary question. In substantive terms, this means that opposition representatives need to make use of their committee expertise and to ask more questions to the 


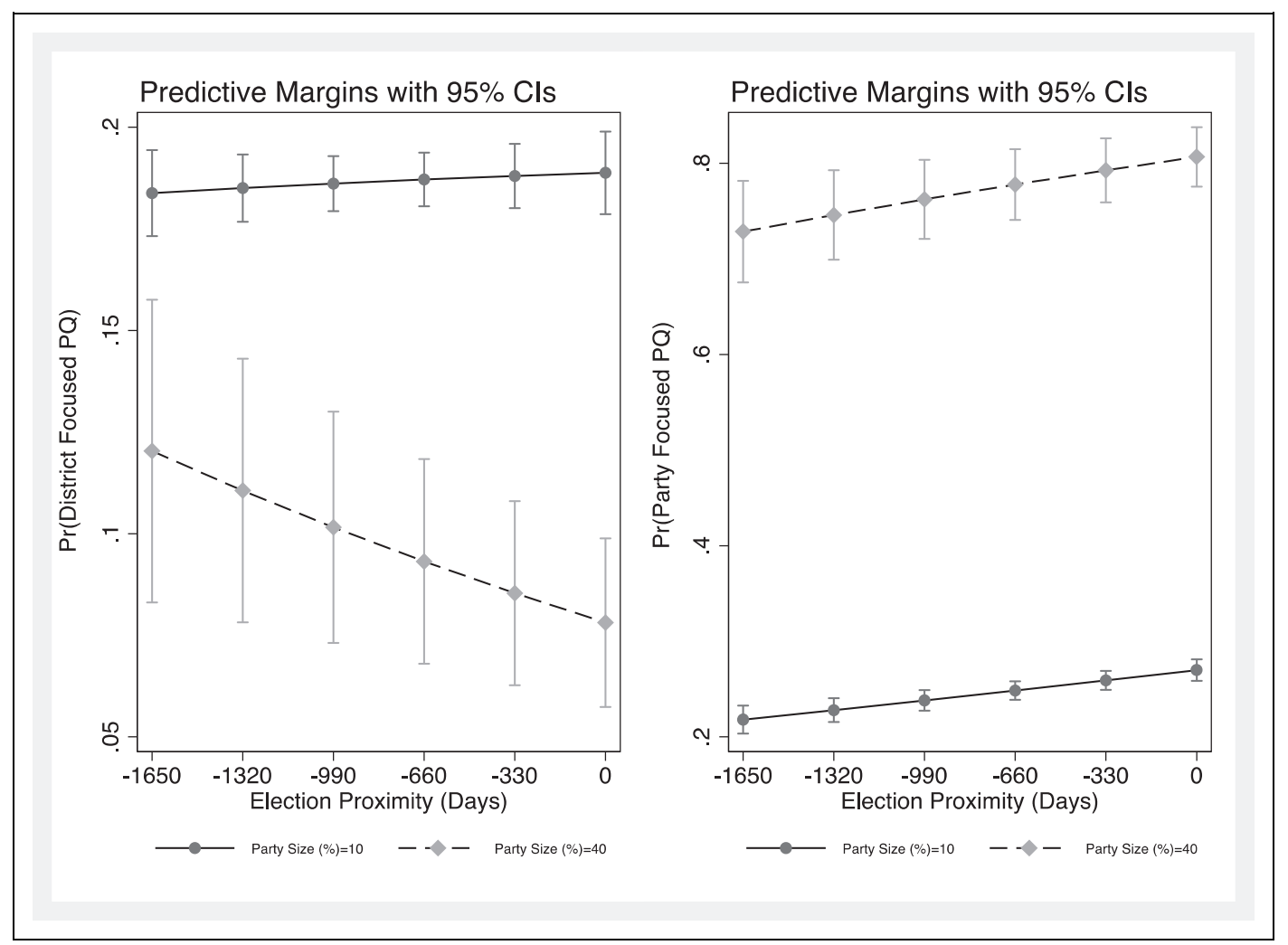

Figure 2. Marginal effects of party size moderated by election proximity.

corresponding ministry on the topic mainly to curb information asymmetry between the executive and the opposition. Finally, our results show that cumul des mandats has a positive effect across the board. Representatives with local government positions have a higher likelihood of tabling questions for both their party and their district. This is a puzzling result that deserves further research.

\section{Conclusion}

In this article, we have explored how parliamentary questions might be used to unveil the focus of representation of representatives in Portugal. We were motivated by a theoretical and empirical puzzle. Is there leeway for representatives to focus on a principal other than their party in a highly institutionally constrained environment? In addition, we wanted to address a question that has been overlooked in the extant literature on parliamentary questions. Do representatives have a time-constant representation focus or do they adapt their focus depending on election proximity? Using an original data set covering the 2005 2015 legislatures in Portugal, this article makes a contribution to the literature by highlighting the importance of including time into our models of parliamentary questioning.

Our main overall contribution for the literature is that representation focus is not static over time. Rather, evidence suggests that representatives are strategic and adapt their behavior accordingly as Election Day approximates. The effect of time differs, however, depending on electoral vulnerability and party size.

First, our empirical evidence suggests that representatives with low electoral vulnerability will be more focused in serving their party toward the end of the legislative term. In substantive terms, this means that frontbenchers of the party (with low electoral vulnerability) will be working toward retrieving as much information as possible to use during the electoral campaign. Conversely, representatives with high electoral vulnerability are more likely to focus on their district. Considering Portuguese institutional setting, with a closed-list proportional representation, those representatives have these incentives because they are the most important to heighten the party's collective label and to boost the aggregate result of the party's list, which will ultimately be decisive for their (re)election due to the uncertainty of the outcome.

Second, the size of the party has an impact in the labor division, which, in turn, makes representatives adapt their behavior during the legislative term. Evidence points out that in large parties (with roughly $40 \%$ of seats), representatives have decreasing incentives to table questions focusing on their district. This suggests that the numerous backbenchers in large parties are less likely to shirk and free ride at the end of the legislative term than at the 
beginning. Such result bodes well with our previous finding on electoral vulnerability, in that backbenchers are more likely to be electorally vulnerable. In contrast, representatives of small parties, where the inherently small number of members makes for a more blurred distinction between frontbenchers and backbenchers, tend to have a more stable behavior over the legislative term.

Our results present some limitations and remaining puzzles requiring further research. Specifically, more work should be put into understanding how party size and organization impacts individual incentives in parliamentary questions. In addition, comparative work should help us shed light on the impact of electoral systems for questioning activity.

\section{Authors' note}

A previous version of this article was presented at the Comparative Politics Workshop at the University of Bamberg, Germany.

\section{Acknowledgements}

The authors would like to thank the editor, David Farrell, and the three anonymous reviewers for their helpful comments and suggestions. The authors would also like to thank Thomas Saalfeld and Mafalda Pratas. All remaining errors and omissions remain our fault.

\section{Declaration of Conflicting Interests}

The author(s) declared no potential conflicts of interest with respect to the research, authorship, and/or publication of this article.

\section{Funding}

The author(s) received no financial support for the research, authorship, and/or publication of this article.

\section{Supplemental material}

The online appendix is available at http://journals.sagepub.com/ doi/suppl/10.1177/1354068817689955

\section{Notes}

1. In this article, we use tabling and asking interchangeability.

2. The formal distinction between frontbenchers and backbenchers does not have formal existence in Portugal.

3. We used a Python script to match parliamentary questions with representative's district of origin. Out of 32,011 questions, about 2000 returned a matching result of more than one district. For example, automated matching returned two hits for "Vila Real" and "Vila Real de Santo António." The former is a city and district in Northern Portugal, while the latter is a municipality in Southern Portugal. Manual coding was used to account for those cases.

4. Committee work is a key part of MPs' parliamentary activity in the Portuguese legislature. All MPs are committee members (Leston-Bandeira 2004: 48-53). See also official records at https://www.parlamento.pt/sites/COM/Paginas/defaultPes quisa.aspx
5. The measure presented in André et al. (2015) is ideal for our purposes for two reasons. First, it uses seats as unit of analysis (and not votes), which is useful to facilitate cross-district comparison and to control for the effect of district magnitude. This is particularly important in Portugal where magnitude varies from 2 (in Portalegre) to 50 (in Lisbon). Second, this measure is inherently focused on intra-party relative vulnerability. In a highly party-constrained partisan environment, we are interested in comparing the differences within parties and not across parties.

6. In Portugal, the capacity to move up the list is limited due to the centralized selection methods of most parties. Consequently, legislators have little incentive to nurture the interests of the party leadership. Instead, they focus on activities at their disposal, that is, fostering the electoral connection using parliamentary questions, which can maximize the party's aggregate electoral result and, in addition, have a marginal effect in the number of candidates the party elects that can make a difference between being reelected or failing that goal.

7. In the Portuguese case, however, the scale can theoretically overcome threshold 1 because of a system of substitutions used routinely. This system of substitutions allows representatives whose list position is below the party's number of elected representatives to take office, thanks to deputies being able to suspend their mandate for a period of time, during which the next candidate on the party list takes their seat. For example, in 2011, the Left Bloc elected three representatives in the Lisbon district, but through a series of substitutions managed to promote Mariana Mortágua, one of the party's rising stars, to a position where she could take office, despite originally being fourteenth in the electoral list.

8. There are, of course, cases, for example, the 2009 legislature, in which the legislative term is curtailed. However, representatives do not have such information when tabling the question. Therefore, our measurement replicates the information level by incorporating uncertainty that representatives have at the moment they table the question.

9. We plot only the effects for parties with 10 and $40 \%$ of the seats, which corresponds to the median in the distribution of size. In the Portuguese legislature, political parties can be divided into two groups: The Socialists (PS) and the Social Democrats (PSD), which historically have around $35-45 \%$ of the seats. The Communists (PCP-PEV), the Left Bloc (BE), and the Christian Democrats (CDS-PP) represent traditionally between $8 \%$ and $12 \%$.

\section{References}

Aldrich J (1995) Why Parties: The Origin and Transformation of Political Parties in America. Chicago: Chicago University Press.

Amacher RC and Boyes WJ (1978) Cycles in senatorial voting behavior: implications for the optimal frequency of elections. Public Choice 33(3): 5-13.

Andeweg R (2000) Fractiocracy? Limits to the ascendency of the parliamentary party group in Dutch politics. In: Heidar K and 
Koole R (eds) Parliamentary Party Groups in European Democracies: Political Parties Behind Closed Doors. London: Routledge, pp. 89-105.

André A, Depauw S and Martin S (2015) Electoral systems and legislators' constituency effort: the mediating effect of electoral vulnerability. Comparative Political Studies 48(4): 464-496.

Bailer S (2011) People's voice or information pool? The role of, and reasons for, parliamentary questions in the Swiss parliament. Journal of Legislative Studies 17(3): 302-314.

Blais A (2006) The causes and consequences of the cumul des mandats. French Politics 4(3): 266-268.

Bowler S and Farrell D (1993) Legislator shirking and voter monitoring: impacts of European parliament electoral systems upon legislator-voter relationships. Journal of Common Market Studies 31(1): 45-70.

Brambor T, Clark WR and Golder M (2006) Understanding interaction models: improving empirical analyses. Political Analysis 14: 63-82.

Cain B, Ferejohn J and Fiorina M (1987) The Personal Vote: Constituency Service and Electoral Independence. Cambridge: Harvard University Press.

Carey J (2007) Competing principals, political institutions and party unity in legislative voting. American Journal of Political Science 51(1): 92-107.

Carey JM and Shugart MS (1995) Incentives to cultivate a personal vote: a rank ordering of electoral formulas. Electoral Studies 14(4): 417-439.

Converse P and Pierce R (1986) Political Representation in France. Cambridge: Harvard University Press.

Costa O, Lefébure P, Rozenberg O, et al. (2012) Far away, so close: parliament and citizens in France. Journal of Legislative Studies 18(3/4): 294-313.

Cox GW and McCubbins MD (1993) Legislative Leviathan: Party Government in the House. Berkeley: University of California Press.

Cox GW and McCubbins MD (2005) Setting the Agenda: Responsible Party Government in the U.S. House of Representatives. Cambridge: Cambridge University Press.

De Winter L and Dumont P (2000) PPGs in Belgium: subjects of Partitocratic Dominion. In: Heidar K and Koole R (eds) Parliamentary Party Groups in European Democracies: Political Parties Behind Closed Doors. London: Routledge, pp: 106-129.

Elling RC (1982) Ideological change in the US senate: time and electoral responsiveness. Legislative Studies Quarterly 7(1): 75-92.

Farrell D and Webb P (2000) Political parties as campaign organizations. In: Dalton R and Wattenberg M (eds) Parties without Partisans: Political Change in Advanced Industrial Democracies. Oxford: Oxford University Press, pp. 102-128.

Fenno R (1973) Congressmen in Committees. Brown: Little.

Fenno R (1978) Home Style: House Members in their Districts. Little: Brown.
Fenno R (1982) United States Senate: A Bicameral Perspective. Washington: AIE Press.

Fernandes JM (2016) Intra-party delegation in the Portuguese legislature: assigning committee chairs and party coordination positions. Journal of Legislative Studies 22(1): $108-128$.

Gilligan TW and Krehbiel T (1987) Collective decision-making and standing committees: an informational rationale for restrictive amendment procedures. Journal of Law, Economics and Organization 3(2): 287-335.

Green-Pedersen C (2010) Bringing parties into parliament: the development of parliamentary activities in Western Europe. Party Politics 16(3): 347-369.

Hagevi M (2000) Parliamentary party groups in the Swedish Riksdag. In: Heidar K and Koole R (eds) Parliamentary Party Groups in European Democracies: Political Parties Behind Closed Doors. London: Routledge, pp: 145-160.

Heidar K and Koole R (2000) Parliamentary Party Groups in European Democracies. London: Routledge.

Kam C (2009) Party Discipline and Parliamentary Politics. Cambridge: Cambridge University Press.

Katz R (1986) A Theory of Parties and Electoral Systems. Baltimore: Johns Hopkins University Press.

Kessler D and Krehbiel K (1996) Dynamics of cosponsorship. American Political Science Review 90(3): 555-566.

Kiewet DR and McCubbins MD (1991) The Logic of Delegation: Congressional Parties and the Appropriations Process. Chicago: Chicago University Press.

Leston-Bandeira C (2004) From Legislation to Legitimation: The Role of the Portuguese Parliament. London: Routledge.

Leston-Bandeira C (2009) Dissent in a party based parliament: the Portuguese case. Party Politics 15(6): 695-713.

Lindstadt R and Wielen RJ (2011) Timely shirking: timedependent monitoring and its effects on legislative behavior in the US senate. Public Choice 148(1): 119-148.

Martin S (2011) Using parliamentary questions to measure constituency focus: an application to the Irish case. Political Studies 59(2): 472-488.

Müller WC (2000) Political parties in parliamentary democracies: making delegation and accountability work. European Journal of Political Research 37(3): 309-333.

Nooteboom B (1993) Firm size effects on transaction costs. Small Business Economics 5(4): 283-295.

Olson M (1965) The Logic of Collective Action: Public Goods and the Theory of Groups. Cambridge: Harvard University Press.

Panebianco A (1988) Political Parties: Organization and Power. Cambridge: Cambridge University Press.

Pequito Teixeira C (2009) O Povo Semi-Soberano - partidos politicos e recrutamento parlamentar em Portugal. Coimbra: Edições Almedina.

Proksch S-O and Slapin J (2011) Parliamentary Questions and Oversight in the European Union. European Journal of Political Research 50(1): 53-79.

Rasch BE (1999) Electoral systems, parliamentary committees, and party discipline: the Norwegian storting in a comparative 
perspective. In: Bowler S, Farrell DM and Katz R (eds) Party Discipline and Parliamentary Government. Columbus: Ohio State University Press, pp 121-140.

Rasch BE (2011) Behavioural consequences of restrictions on plenary access: parliamentary questions in the Norwegian Storting. Journal of Legislative Studies 17(3): 382-393.

Rozenberg O and Martin S (2011) The role of function of parliamentary questions: an assessment. Journal of Legislative Studies 17(3): 394-404.

Rozenberg O, Chopin O, Hoeffler C, et al. (2011) Not only a battleground: parliamentary oral questions concerning defence policies in four western democracies. Journal of Legislative Studies 17(3): 340-353.

Russo F and Wiberg M (2010) Parliamentary questioning in 17 European parliaments: some steps towards comparison. Journal of Legislative Studies 16(2): 215-232.

Saalfeld T (2000a) Members of parliament and governments in Western Europe: agency relations and problems of oversight. European Journal of Political Research 37(3): 356-376.

Saalfeld T (2000b) Bureaucratisation, coordination and competition: parliamentary party groups in the German Bundestag. In: Heidar K and Koole R (eds) Parliamentary Party Groups in European Democracies: Political Parties Behind Closed Doors. London: Routledge, pp. 23-38.

Sánchez de Dios M and Wiberg M (2011) Questioning in European parliaments. Journal of Legislative Studies 17(3): 354-367.

Sartori G (1976) Parties and Party Systems: A Framework for Analysis. Cambridge: Cambridge University Press.
Shepsle K, van Houweling RP, Abrams SJ, et al. (2009) The senate electoral cycle and bicameral appropriations politics. American Journal of Political Science 53(2): 343-359.

Shugart MS, Valdini ME and Suominen K (2005) Looking for locals: voter information demands and personal vote-earning attributes of legislators under proportional representation. American Journal of Political Science 49(2): 437-449.

Sieberer U (2006) Party unity in parliamentary democracies: a comparative analysis. Journal of Legislative Studies 12(2): $150-178$.

Strøm K (1997) Rules, reasons and routines: legislative roles in parliamentary democracies. Journal of Legislative Studies 3(1): 155-174.

Thomas M (1985) Election proximity and senatorial roll call voting. American Journal of Political Science 29(1): 96-111.

Wiberg M (1995) Parliamentary questioning: control by communication? In: Doring H (ed) Parliaments and Majority Rule in Western Europe. Frankfurt: Campus Verlag, pp 179-222.

\section{Author biographies}

Jorge M. Fernandes is a postdoctoral fellow at the University of Bamberg, Germany.

Cristina Leston-Bandeira is a professor of politics at the University of Leeds, UK.

Carsten Schwemmer is a research fellow at the University of Bamberg, Germany. 